University of Nebraska - Lincoln

DigitalCommons@University of Nebraska - Lincoln

U.S. Environmental Protection Agency Papers

U.S. Environmental Protection Agency

2007

\title{
CCA-Treated wood disposed in landfills and life-cycle trade-offs with waste-to-energy and MSW landfill disposal
}

Jenna Jambeck

University of New Hampshire, jenna.jambeck@unh.edu

Keith Weitz

RTI International, kaw@rti.org

Helena Solo-Gabriele

University of Miami, hmsolo@miami.edu

Timothy Townsend

University of Florida, ttown@ufl.edu

Susan Thorneloe

U.S. EPA, thorneloe.susan@epa.gov

Follow this and additional works at: https://digitalcommons.unl.edu/usepapapers

Jambeck, Jenna; Weitz, Keith; Solo-Gabriele, Helena; Townsend, Timothy; and Thorneloe, Susan, "CCATreated wood disposed in landfills and life-cycle trade-offs with waste-to-energy and MSW landfill disposal" (2007). U.S. Environmental Protection Agency Papers. 170.

https://digitalcommons.unl.edu/usepapapers/170

This Article is brought to you for free and open access by the U.S. Environmental Protection Agency at DigitalCommons@University of Nebraska - Lincoln. It has been accepted for inclusion in U.S. Environmental Protection Agency Papers by an authorized administrator of DigitalCommons@University of Nebraska - Lincoln. 


\title{
CCA-Treated wood disposed in landfills and life-cycle trade-offs with waste-to-energy and MSW landfill disposal
}

\author{
Jenna Jambeck ${ }^{\mathrm{a}, *}$, Keith Weitz ${ }^{\mathrm{b}}$, Helena Solo-Gabriele ${ }^{\mathrm{c}}$, Timothy Townsend ${ }^{\mathrm{d}}$, \\ Susan Thorneloe ${ }^{\mathrm{e}}$ \\ a Department of Civil Engineering, University of New Hampshire, ERG, Durham, NH, USA \\ ${ }^{\mathrm{b}}$ RTI International, Research Triangle Park, NC, USA \\ ${ }^{\mathrm{c}}$ Department of Civil, Architecture, and Environmental Engineering, University of Miami, Coral Gables, FL, USA \\ ${ }^{\mathrm{d}}$ Department of Environmental Engineering Sciences, University of Florida, Gainesville, FL, USA \\ ${ }^{\mathrm{e}}$ US EPA, ORD, APPCD, Research Triangle Park, NC, USA
}

Accepted 16 February 2007

Available online 9 April 2007

\begin{abstract}
Chromated copper arsenate (CCA)-treated wood is a preservative treated wood construction product that grew in use in the 1970s for both residential and industrial applications. Although some countries have banned the use of the product for some applications, others have not, and the product continues to enter the waste stream from construction, demolition and remodeling projects. CCA-treated wood as a solid waste is managed in various ways throughout the world. In the US, CCA-treated wood is disposed primarily within landfills; however some of the wood is combusted in waste-to-energy (WTE) facilities. In other countries, the predominant disposal option for wood, sometimes including CCA-treated wood, is combustion for the production of energy. This paper presents an estimate of the quantity of CCA-treated wood entering the disposal stream in the US, as well as an examination of the trade-offs between landfilling and WTE combustion of CCA-treated wood through a life-cycle assessment and decision support tool (MSW DST). Based upon production statistics, the estimated life span and the phaseout of CCA-treated wood, recent disposal projections estimate the peak US disposal rate to occur in 2008, at 9.7 million $\mathrm{m}^{3}$. CCA-treated wood, when disposed with construction and demolition (C\&D) debris and municipal solid waste (MSW), has been found to increase arsenic and chromium concentrations in leachate. For this reason, and because MSW landfills are lined, MSW landfills have been recommended as a preferred disposal option over unlined C\&D debris landfills. Between landfilling and WTE for the same mass of CCA-treated wood, WTE is more expensive (nearly twice the cost), but when operated in accordance with US Environmental Protection Agency (US EPA) regulations, it produces energy and does not emit fossil carbon emissions. If the wood is managed via WTE, less landfill area is required, which could be an influential trade-off in some countries. Although metals are concentrated in the ash in the WTE scenario, the MSW landfill scenario releases a greater amount of arsenic from leachate in a more dilute form. The WTE scenario releases more chromium from the ash on an annual basis. The WTE facility and subsequent ash disposal greatly concentrates the chromium, often oxidizing it to the more toxic and mobile Cr(VI) form. Elevated arsenic and chromium concentrations in the ash leachate may increase leachate management costs.
\end{abstract}

(c) 2007 Elsevier Ltd. All rights reserved.

\footnotetext{
${ }^{*}$ Corresponding author. Tel.: +1 603862 4023; fax: +1 6038623957.

E-mail addresses: jenna.jambeck@unh.edu (J. Jambeck), kaw@rti.org (K. Weitz), hmsolo@miami.edu (H. Solo-Gabriele), ttown@ufl.edu (T. Townsend), thorneloe.susan@epa.gov (S. Thorneloe).
}

\section{Introduction and background}

Because of the metal content of CCA-treated wood, it has been relatively difficult to manage as a solid waste. Under US EPA standardized testing conditions, CCA-treated wood shows characteristics of a hazardous waste because of the leachability of arsenic and chromium (Townsend et al., 2004), yet it is exempt from federal regulation as a hazardous 
waste in the US (CFR, 2003). CCA-treated wood may become commingled in the municipal solid waste (MSW) stream and managed along with MSW in regulated landfills. CCA-treated wood, when co-disposed with MSW, has been found to increase arsenic and chromium concentrations in leachate (Jambeck, 2004). Since wood is a construction product, CCA-treated wood is often managed as construction and demolition (C\&D) debris when discarded (Solo-Gabriele and Townsend, 1999).

C\&D Debris is often targeted for recycling. CCA-treated wood mixed in with recycled wood can contaminate mulch made from this recycled wood (Townsend et al., 2003; Solo-Gabriele et al., 2004). If CCA-treated wood is incinerated, it releases emissions of arsenic that must be captured in accordance with US requirements; and arsenic, copper and chromium become concentrated in the ash (Solo-Gabriele et al., 2002; Iida et al., 2004). Also, when CCA-treated wood is incinerated, the chromium can be oxidized into the more toxic and mobile form of chromium, $\mathrm{Cr}(\mathrm{VI})$ (Song et al., 2006). Some countries (e.g., Germany) ban the wood (materials with total organic carbon greater than 5\% banned) from landfill disposal and, after all reuse options have been exhausted, require it to be incinerated (Peek, 2004). Furthermore, the EU Landfill Directive includes targets for the diversion of landfilled biodegradable waste at $75 \%$ of the 1995 level within 5 years of implementation, $50 \%$ of the 1995 level 8 years after implementation and $35 \%$ of the 1995 level within 15 years after implementation (European Union, 1999). Currently in the US, CCA-treated wood is typically disposed in landfills. In the US, $54 \%$ of the states do not require bottom liners for C\&D debris landfills (Clark et al., 2006). Therefore, leachate produced at these landfills infiltrates the underlying ground. Co-disposal of CCA-treated wood with C\&D debris has been shown to elevate arsenic and chromium concentrations in the leachate (Jang and Townsend, 2003; Jambeck, 2004).

A voluntary phase out of CCA-treated wood took effect January 1, 2004 for most residential uses (US EPA, 2002). This phase out of treated wood production was initiated due to concerns associated with possible health effects from contact with treated wood and the availability of non-arsenical wood preservatives (US EPA, 2001, 2002, 2003). However, because of the 10-40 year service life of treated wood (McQueen and Stevens, 1998; Alderman et al., 2003; Cooper, 1994; Solo-Gabriele and Townsend, 1999), disposal of CCA-treated wood will continue long into the future. Cooper (1994) estimated and projected amounts of CCA-treated wood removed from service in both the US and Canada. These projections estimated the amounts of CCA-treated wood coming out of service in the year 2010 at approximately 10 million $\mathrm{m}^{3}$ in the US and 0.8 million $\mathrm{m}^{3}$ in Canada. The impacts to of treated wood within different waste management options (e.g., incineration and landfilling) have been evaluated (Jang and Townsend, 2003; Solo-Gabriele et al., 2002; Iida et al., 2004; Jambeck, 2004).

However, regulators and the solid waste industry continue to struggle with identifying the best management option for the treated wood waste. The Waste and Resources Action Program (WRAP) in the United Kingdom has recently completed a report assessing the options and risk for treated wood management as well (WRAP, 2005). Since MSW landfills are required to be lined in the US, disposal in an MSW landfill has been recommended; however, the other option to landfilling is combusting the wood and recovering the energy. The WRAP (2005) discusses combustion with energy recovery as well, and the European Waste Incineration Directive (WID) provides various guidelines for this practice including air emission guidelines. This paper begins to explore this dilemma by examining the differences between the management of CCA-treated wood via WTE or MSW landfills in the US, with a more detailed case study of these disposal scenarios for the State of Florida. Although CCA-treated wood is currently primarily managed in $C \& D$ debris landfills in Florida, Florida is considering new regulations, and the purpose of this study was to evaluate new options for management, in addition to those currently used.

The municipal solid waste decision support tool (MSW DST) is a linear programming (LP)-based decision model to aid in identifying environmentally and economically efficient strategies for integrated MSW management (Solano et al., 2002a,b). The tool was developed by the US EPA's National Risk Management Research Laboratory (NRML) in cooperation with RTI International and North Carolina State University (NCSU). Environmental and economic aspects for hypothetical integrated solid waste management alternatives are estimated using life-cycle assessment and full-cost accounting methodologies, respectively (Weitz et al., 1999). The tool provides a quantitative comparison of many aspects taken into consideration when waste management decisions are made, including cost and many environmental parameters such as emissions of carbon monoxide $(\mathrm{CO})$, carbon dioxide $\left(\mathrm{CO}_{2}\right)$ (both biomass and fossil fuel derived), nitrogen oxides $\left(\mathrm{NO}_{x}\right)$, sulfur oxides $\left(\mathrm{SO}_{x}\right)$, total particulate matter $(\mathrm{PM})$, carbon equivalents (MTCE), energy consumption and metals released into the environment. The model bases calculated emissions on the entire waste management system including waste collection, transportation, recycling, treatment, and disposal (Thorneloe and Weitz, 2004). The holistic nature of this model made it a useful tool in comparing the environmental aspect resulting from landfill disposal or management via WTE of CCA-treated wood. It should be noted that the tool does not include the emissions associated with CCA-treated wood production or use, but instead assesses the waste management section of the life-cycle of CCA-treated wood.

\section{Methods}

\subsection{CCA-treated wood management scenarios and MSW DST input}

The MSW DST contains life-cycle environmental data for waste collection, transport, recycling, composting, 
WTE and landfilling; for the production and consumption of energy for the US national and regional grids; and for the production of aluminum, glass, paper, plastic, and steel (Thorneloe and Weitz, 2004). The tool also includes US waste composition data that includes a wood component that was used to simulate the disposal of CCA-treated wood (for purposes of correctly estimating BTU values). The tool required the input of a quantity of wood, which is taken through the entire waste management system calculating and totaling life cycle energy consumption and emissions on an annual basis. The hypothetical situation used in the tool was to examine the differences between the management of CCA-treated wood via WTE or MSW landfills. A total of four scenarios were simulated by the model: (1) the mass of CCA-treated wood estimated to be entering the disposal stream in the US $\left(9.7\right.$ million $\mathrm{m}^{3}$ in 2007) managed in MSW landfills and (2) managed 50\% in MSW landfills and $50 \%$ by WTE; (3) the mass of CCAtreated wood estimated to enter the Florida disposal stream (0.6 million $\mathrm{m}^{3}$ in 2007) managed in MSW landfills, and (4) $100 \%$ managed by WTE. The waste collection settings did not differ between the management options. For transportation, no transfer stations were considered and the two scenarios were equal, except for the WTE scenario, which included transportation of the ash to an ash landfill. The primary difference between the landfill and WTE scenarios was the treatment and disposal of the mass of CCA-treated wood. In the US WTE scenario, the simulation consisted of sending $50 \%$ of the wood to a WTE facility and disposal of the ash in a landfill. The remaining 50\% of the wood was directly landfilled in an MSW landfill. In the Florida WTE scenario, $100 \%$ the wood was sent to a WTE facility and the ash was landfilled. In the $100 \%$ landfill scenarios for both the US and Florida, all of the wood was sent to a traditional MSW landfill. Table 1 outlines the input values for each process model of the tool.

The WTE scenarios assume the air pollution control system is in compliance with US requirements. In the traditional landfill scenario, the landfill gas is assumed to be flared, which although not necessarily typical for Europe, is still typical for the US. Carbon emissions can result from the combustion of fossil fuels and the biodegradation of organic materials (e.g., methane gas from landfills). Offsets of carbon emissions can result from the displacement of fossil fuels, materials recycling, and the diversion of organic wastes from landfills. Carbon emissions in units of tonnes are calculated in the model as follows: [(Fossil $\left.\left.\mathrm{CO}_{2}+\mathrm{CH}_{4} * 21\right) * 12 / 44\right] / 2000$.

\subsection{Estimate of disposal of CCA-treated wood in the US}

The amount of CCA-treated wood entering the US disposal stream (Fig. 1) was calculated based upon production statistics, estimated life span and the phaseout of CCAtreated wood. A similar model was developed for the state of Florida (Khan et al., 2006a,b). Annual production statistics and industry forecasts were used to estimate quantities of CCA-treated wood produced in any give year $\left(P_{i}\right)$ from 1960 through 2003 (AWPA, 1960-1997; AWPI, 1995 and 1996). Quantities included data for two general categories of treated wood: lumber \& timbers, and utility poles.

Removal of treated wood was assumed to occur through construction waste and through demolition waste. Construction waste, $W_{i}$, was assumed to be disposed within the same year that the wood was produced and was esti-

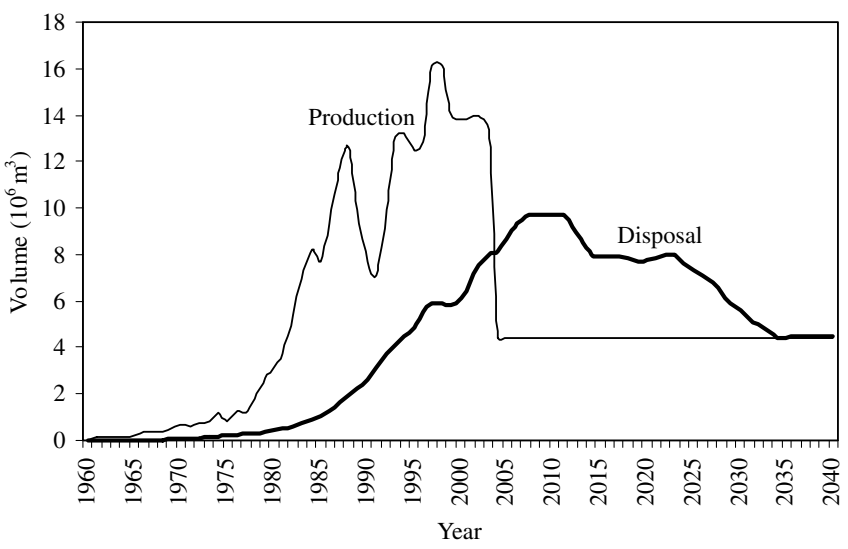

Fig. 1. CCA-Treated wood disposal projection for the US.

Table 1

Inputs for the MSW DST scenarios

\begin{tabular}{|c|c|c|c|c|}
\hline & US MSW landfill scenario & US 50:50 Landfill/WTE & FL MSW landfill scenario & FL WTE scenario \\
\hline \multirow{2}{*}{ Collection } & Same in each scenario & Same in each scenario & Same in each scenario & Same in each scenario \\
\hline & Transportation & No transfer stations considered & $\begin{array}{l}\text { No transfer stations } \\
\text { considered }\end{array}$ & $\begin{array}{l}\text { No transfer stations } \\
\text { considered }\end{array}$ \\
\hline $\begin{array}{l}\text { Transport of } \\
\text { ash }\end{array}$ & Transport of ash considered & No other transport needed & Transport of ash considered & \\
\hline Recycling & None & None & None & None \\
\hline Heat rate & Not applicable & Heat rate of $18,000 \mathrm{BTU} / \mathrm{kWh}$ & Not applicable & $\begin{array}{l}\text { Heat rate of } 18,000 \mathrm{BTU} / \\
\mathrm{kWh}\end{array}$ \\
\hline Mass disposed & 4.8 million tonnes (wood) & $\begin{array}{l}2.4 \text { million tonnes (wood) } \\
271,400 \text { tonnes (ash) }\end{array}$ & 336,000 tonnes (wood) & 38,000 tonnes (ash) \\
\hline
\end{tabular}


mated at $2.5 \%$ of the production quantity (Cooper, 1994). Demolition waste is wood disposed at the end of the treated wood service life. Three service lives were used. The service life for lumber and timber used for residential decks, $D_{1 \mathrm{a}, i}$, was estimated at an average of 10 year (McQueen and Stevens, 1998; Alderman et al., 2003), the service life for the remaining lumber and timbers used for transportation, marine, and industrial uses, $D_{1 \mathrm{~b}, i}$, was estimated at an average of 25 year, and the service life of utility poles, $D_{2, i}$, was estimated at 40 year (Cooper, 1994; Gutzmer and Crawford, 1995). Since industry statistical reports used to obtain lumber and timber quantities did not distinguish between the uses of these for decks versus other uses, it was assumed that in any given year an estimated $60 \%$ of these products were intended for residential applications and $40 \%$ used for highway, marine, and industrial purposes. This distribution of the different categories of CCA-treated wood products is consistent with those established by the Southern Forest Products Association (SFPA, 2000). The total disposal volume during year $i$, $D_{i}$, expressed in units of million cubic meters, was therefore equal to the sum of the off-cut waste plus end-of-service life waste as estimated from each of the sub-models (Eq. (1)).

$D_{\mathrm{T}, i}=W_{i}+D_{1 \mathrm{a}, i}+D_{1 \mathrm{~b}, i}+D_{2, i}$

In order to extend the forecast beyond 2004, the production of lumber and timbers used for decks, $D_{1 \mathrm{a}, i}$, was estimated at $30 \%$ of the quantity produced during 2003 (representing the applications of CCA-treated wood still available for use). The production of utility poles, $D_{2, i}$, and lumber and timber for the remaining uses, $D_{1 \mathrm{~b}, i}$, were assumed to remain at $100 \%$ of 2003 levels, as these products were not included in the phase out. The model simulates production and disposal through the year 2040. Based upon the above disposal estimates, the mass of CCA-treated wood is forecasted to vary between the years 2000 through 2030 at 6-10 million $\mathrm{m}^{3}$ per year in the US and $0.4-0.7$ million $\mathrm{m}^{3}$ per year in Florida. The mass put through the model in each respective case were for 2007, 9.7 million $\mathrm{m}^{3}$ for the US and 0.6 million $\mathrm{m}^{3}$ for Florida. The results of this disposal forecast were used within the MSW DST.

\subsection{MSW landfill and ash leachate concentrations}

Previous experiments conducted by the authors utilizing simulated landfills (lysimeters) showed that disposal of
CCA-treated wood can impact arsenic, chromium and copper concentrations in leachate. A simulated MSW landfill containing a quantity of $2 \%$ CCA-treated wood provided an estimate, as well as showed trends of arsenic, copper, and chromium leachate concentrations; further details on the methods and results may be found in Jambeck, 2004. The leachate concentrations used for the MSW landfill scenario in the MSW DST were the average concentrations resulting from the simulated landfill experiment reported in Jambeck (2004). For arsenic this value was $0.54 \mathrm{mg} / \mathrm{L}$ and for chromium it was $0.195 \mathrm{mg} / \mathrm{L}$.

The ash landfill leachate concentrations were estimated by previous research (Solo-Gabriele et al., 2002) for ash made from 5\% CCA-treated wood with the balance from untreated wood. Of note was that the ash made from $5 \%$ CCA-treated wood when subject to the toxicity characteristic leaching procedure (TCLP) exceeded the toxicity characteristic limit (5 mg/L of arsenic and chromium), classifying it as a hazardous waste (Solo-Gabriele et al., 2002). Therefore, if 5\% CCA-treated wood was actually fed into a WTE facility, the ash would likely need to be managed as a hazardous waste (and smaller percentages in Europe could be considered hazardous under the Landfill Directive). This would greatly increase the cost of the WTE option in the model. However, the ash evaluated by Solo-Gabriele et al. (2002) was also subjected to the synthetic precipitation leaching procedure (SPLP), and these concentrations were used as the input to the model (as no other ash leachate disposal numbers were available). Using the 5\% CCA-treated wood SPLP leachate estimate for the ash in the model is conservative; this concentration is likely higher than would normally be encountered from ash since it is likely that a lower percentage by mass of CCA-treated wood would actually be incinerated at a WTE facility. Leachate concentrations for both arsenic and chromium were input into the model for each scenario as shown in Table 2. Copper leachate concentrations were not included in the model since copper was not shown to be out of the range of normal landfill concentrations in the lysimeter study and also was reported as below $0.05 \mathrm{mg} / \mathrm{L}$ in the ash leachate results.

In the model, the WTE air pollution control system collects any potential airborne metals in the fly ash. Then, the fly ash and bottom ash are disposed of together. Therefore, the only metal emissions from each scenario are produced from the disposal module (MSW or ash). The disposal module was tailored to Florida by utilizing an annual rain-

Table 2

Inputs for the Florida case study

\begin{tabular}{lll}
\hline & FL MSW landfill scenario & FL WTE scenario \\
\hline Precipitation & $127 \mathrm{~cm} /$ year & $127 \mathrm{~cm} /$ year \\
Mass disposed & 336,000 tonnes (wood) & 38,000 tonnes (ash) \\
Quantity of leachate generated in 2007 from disposing & 29.2 million L & $1.24 \mathrm{million} \mathrm{L}$ \\
$\quad$ & & $931 \mathrm{~m}^{2}(0.23 \mathrm{acres})$ \\
Areod/ash & $21,850 \mathrm{~m}^{2}(5.4 \mathrm{acres})$ & Arsenic $-1.76 \mathrm{mg} / \mathrm{L} \mathrm{Chromium}-$ \\
Leachate concentration & Arsenic $-0.54 \mathrm{mg} / \mathrm{L} \mathrm{Chromium} \mathrm{-}$ & $4.79 \mathrm{mg} / \mathrm{L}$ \\
& $0.195 \mathrm{mg} / \mathrm{L}$ & \\
\hline
\end{tabular}


fall rate of $127 \mathrm{~cm} /$ year. The resulting rate of arsenic and chromium release from the landfill itself is reported here (before treatment). The amount of metal released by the landfill itself is reported because that quantity of each metal will have to ultimately be managed by pollution control systems. However, it should be noted that the amount of metals estimated to be released from the landfills would actually be collected through leachate collection systems and treated.

The MSW DST estimates leachate generation over the life of the landfill for 500 years. This estimation is completed in a step-wise fashion with a percentage of precipitation encountering the landfill becoming leachate. For Leachate Production Period 1 (waste is $0-1.5$ year old), $20 \%$ of precipitation becomes leachate. For Leachate Production Period 2 (waste is $1.5-5$ year old), $6.6 \%$ of precipitation becomes leachate. For Leachate Production Period 3 (waste is $5-10$ year old), $6.5 \%$ of precipitation becomes leachate. And finally for the final Leachate Production Period 4 , when the waste is 10 year old and older, $0.04 \%$ of the precipitation becomes leachate. This method of calculation allowed an estimate of the total amount of arsenic and chromium released in each landfill disposal situation to be generated based upon the precipitation amount and the concentration of the leachate. Leachate generation was also calculated on a per ton basis of material landfilled (waste or ash). This allowed both the amount of leachate generated in the respective model year, as well as the amount of each metal, to be calculated.

\section{Results and discussion of trade-offs}

Fig. 2 provides the comparable yearly costs (for landfilling versus WTE only), energy consumption and carbon equivalents emitted by the four scenarios. While WTE results in a net offset of energy production in the utility sector and emits less carbon, it is nearly double the cost of landfilling because of the higher construction and operation costs (resulting in higher tipping fees). This is a significant trade-off since economics often play the largest role in decision-making. However, as energy supplies become limited and carbon emission (e.g., greenhouse gas) issues continue to become more important, economics may become less influential. The default cost values for the US were used in the model to calculate the cost estimate and the cost comparison takes into account the sale of electricity for the WTE facility, but does not take into account the cost of land for respective land use between WTE and landfilling. The difference in the US management scenarios and the Florida management scenarios are due to differences in the mass of wood in the disposal stream and the proportion of wood sent to the WTE. However, as illustrated by Fig. 2, even if $50 \%$ of the wood is managed through WTE in the US, significant net savings on energy and carbon emissions can be achieved.

Fig. 3 shows the difference between the arsenic released in 2007 (the mass of wood managed in 2007) by the two
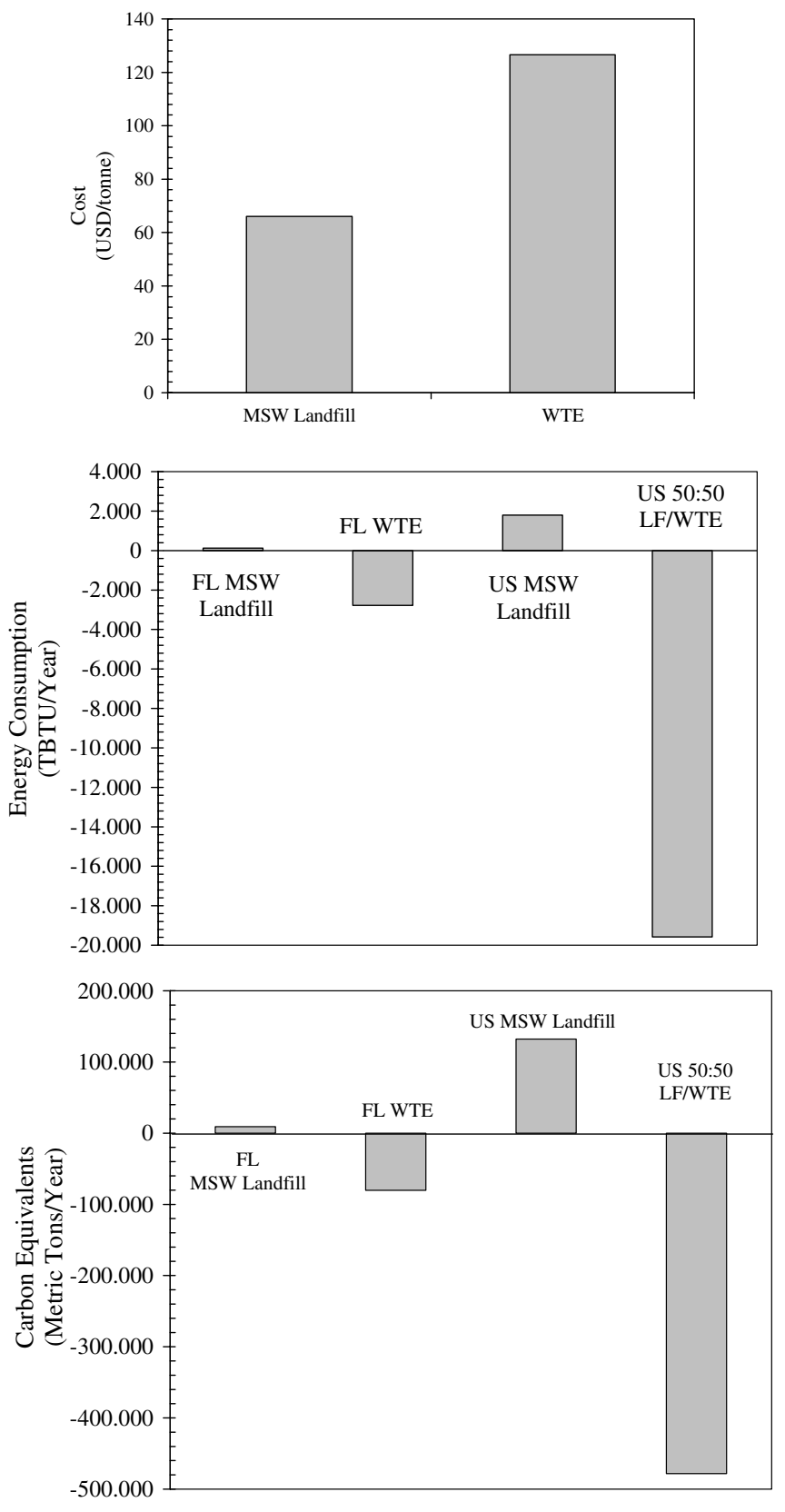

Fig. 2. MSW DST results for cost, annual energy consumption, carbon emissions.

disposal scenarios (MSW versus ash) for the detailed Florida case study. Although the concentration of arsenic in the leachate from the ash is over 3 times greater than the concentration from MSW $(1.76 \mathrm{mg} / \mathrm{L}$ versus $0.54 \mathrm{mg} / \mathrm{L})$, the fact that the mass of ash landfilled is less results in a lower total arsenic release as well. For chromium, also shown in Fig. 3, the annual rate of release is greater for the ash since the leachate concentration from the ash is 24 times greater than the leachate concentration from the MSW $(4.8 \mathrm{mg} / \mathrm{L}$ versus $0.2 \mathrm{mg} / \mathrm{L}$ ). During the combustion process, a portion of the chromium as $\mathrm{Cr}$ (III) (which is the species typically found in CCA-treated wood) is transformed to the more toxic and mobile hexavalent form $(\mathrm{Cr}(\mathrm{VI})$ ) (Song 


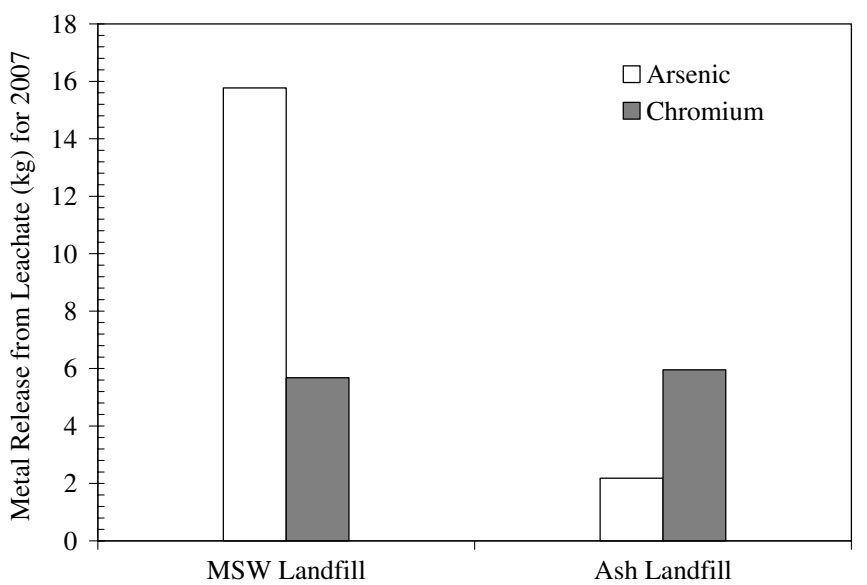

Fig. 3. Modeled arsenic and chromium release rates for CCA-treated wood disposed in Florida in 2007.

et al., 2006). The increased concentration of chromium in the ash leachate is thus a combination of the increased concentration of metals in the ash, due to removal of the organic portion of the wood, plus a conversion of the chromium towards $\mathrm{Cr}(\mathrm{VI})$.

Since arsenic and chromium are concentrated in the WTE ash and the leachate concentrations are greater, on a per unit area basis, the amount of metals released is greater (as shown in Fig. 4). However, the land use trade-off associated with this should be considered. As shown in Table 2, ash disposal would require $931 \mathrm{~m}^{2}$ (less than 1 acre) of land per year, while the MSW disposal scenario would require $21,850 \mathrm{~m}^{2}$ (over 5 acres). Land requirements could be a significant trade-off in areas where land is scarce and expensive and this trade-off can heavily influence decision-making. In the US, where land is often plentiful, MSW landfilling still thrives. For some countries in Europe and Asia, incineration/WTE is more popular since it greatly reduces the amount of land needed for disposal.

The MSW landfill scenario is estimated to release more arsenic for the simulation year, but it is less concentrated both in the waste $(2 \%$ of the waste stream in MSW) and

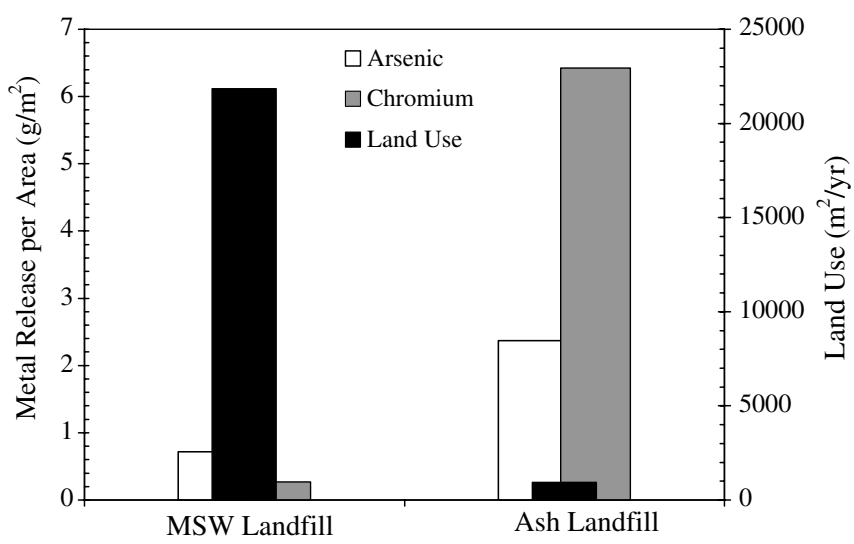

Fig. 4. Modeled arsenic and chromium release per unit area and disposal land use in florida in 2007. in the leachate generated from this waste. The ash disposal scenario is estimated to release less over the year, but arsenic concentrations are more concentrated in the ash and in the leachate. If, in both scenarios, the landfills are lined and the leachate is collected, the local groundwater may be protected and the metals released could then be managed through wastewater treatment. In the case of lined landfills, some of the other trade-offs (e.g., cost, land use, energy) may have more influence in the decision-making process. The higher concentration of arsenic and chromium in the ash leachate in comparison to MSW leachate could increase leachate management costs based on concentration; however, overall leachate volumes are smaller in the ash scenario (see Table 2).

The results of this study may be affected by several factors including the cost of disposal of the incinerator ash if it does indeed become a hazardous waste (would increase costs), the transportation from collection for the WTE option is greater than that for landfilling (would increase air emissions), and the leachate concentrations of the MSW landfill and ash (may change over time resulting in different metal release rates). Limitations of this model are that a constant concentration is assumed for the leachate. Both arsenic and chromium concentrations will be dynamic, changing over time and with varying chemistry within each respective disposal scenario. As presented here, the model results do provide a relative comparison between the two management scenarios for CCA-treated wood given the input parameters incorporated into the model.

\section{Summary}

CCA-treated wood disposal estimates for the US were calculated. Based upon this disposal estimate, the mass of CCA-treated wood is forecasted to vary between the years 2000 through 2030 at $6-10$ million $\mathrm{m}^{3}$ per year in the US. In Florida the quantity varies from 0.4 to 0.7 million $\mathrm{m}^{3}$ per year. Between landfilling and WTE options for the same mass of CCA-treated wood, WTE is more expensive (nearly twice the cost), but when operated in accordance with US EPA regulations, it produces energy and does not emit fossil carbon emissions. Although arsenic and chromium are concentrated in the ash, the mass of disposed ash is less than the mass of wood disposed within MSW. Therefore, the WTE disposal scenario releases arsenic at a slower rate on an annual basis. However, the total amount of each metal (e.g., arsenic and chromium) requiring disposal on an annual basis is the same in each situation, whether it be landfilled or managed via WTE. There is complex chemistry involved in the release of both arsenic and chromium from both the MSW and ash landfill situation, which in this case are estimated through lysimeters containing simulated wastes and from bench-scale ash leaching tests, and are limited by the assumption that leaching is constant over time.

The MSW landfill scenario releases more arsenic on an annual basis, but it is less concentrated in the waste dis- 
posed and in the leachate. The WTE facility and subsequent ash disposal scenario releases less arsenic on an annual basis, but it is more concentrated in the ash and in the leachate. The WTE facility and subsequent ash disposal greatly concentrates the chromium, and often oxidizes it to $\mathrm{Cr}(\mathrm{VI})$ making it more toxic and mobile. If, in both scenarios, the landfills are lined and the leachate is to be collected, the local groundwater may be protected and the metals released could then be managed through wastewater treatment. Higher concentration of arsenic and chromium in the ash leachate (when compared to the MSW leachate) could increase management costs, however. If the wood is managed via WTE, less landfill area is required, which could be an influential trade-off in some countries. Since managing wood via WTE provides beneficial energy and reduces the mass of waste landfilled, further research may be warranted on the actual impacts of CCAtreated wood to WTE facilities, especially MSW facilities, including an evaluation of air pollution efficiencies and the long term leaching of the disposed ash.

\section{Acknowledgements}

Special thanks is given to Dr. Morton Barlaz at North Carolina State University. Although the MSW DST is associated with the US EPA, this research has not been reviewed by the US EPA, nor does it reflect the views of the US EPA; no official endorsement should be inferred. This project was supported in part by an appointment to the Research Participation Program at the National Risk Management Research Laboratory administered by the Oak Ridge Institute for Science and Education through an interagency agreement between the US Department of Energy and the US Environmental Protection Agency. The authors also acknowledge the support from the Florida Center for Solid and Hazardous Waste Management, who sponsored the research focusing on the disposal forecast for CCA-treated wood.

\section{References}

Alderman, D., Smith, R., Araman, P., 2003. A profile of CCA-treated lumber removed from service in the southeastern United States decking market. Forest Products Journal 53 (1), 38-45.

AWPA, 1960-1997. In: Annual Proceedings of the American Wood Preservers Association. AWPA: Selma, Alabama, 1960-1981, 19831988, 1990-1991, 1997.

AWPI, 1995 and 1996. Preserving Industry Production Statistical Reports. American Wood Preservers' Institute, Fairfax, Virginia, 1995 and 1996.

Code of Federal Regulations (CFR), 2003. Title 40 -Protection of the Environment, Chapter 1 - Environmental Protection Agency, Part 261 - Identification and Listing of Hazardous Waste.

Clark, C., Jambeck, J., Townsend, T., 2006. A review of construction and demolition debris regulations in the US. Critical Reviews in Environmental Science and Technology 36, 141-186.

Cooper, P.A., 1994. Disposal of treated wood removed from service: the issues. In: Environmental Considerations in the Manufacture, Use and Disposal of Preservative-treated Society, Wood, Forest Products Madison, WI, pp. 85-90.
European Union 1999. Council Directive 1999/31/EC of 26 April 1999 on the landfill of waste, Official Journal of the European Communities 16.7.1999.

United States Environmental Protection Agency (US EPA) 2001. Preliminary evaluation of the non-dietary hazard and exposure to children from contact with chromated copper arsenate (CCA)-treated wood playground structures and CCA-contaminated soil. In: FIFRA Scientific Advisory Panel Meeting, October 23-25, 2001, held at the Sheraton Crystal City Hotel, Arlington, Virginia, SAP Report No. 2001-12.

Gutzmer, D.I., Crawford, D.M., 1995. Comparison of Wood Preservatives in Stake Tests, 1995 Progress Report, FPL-RN-02. US Department of Agriculture, Forest Products Laboratory: Madison, Wisconsin.

Iida, K., Pierman, J., Tolaymat, T., Townsend, T., Wu, C., 2004. Control of heavy metal emissions and leaching from incineration of CCAtreated wood using mineral sorbents. Journal of Environmental Engineering, ASCE 1302 (2), 184-192.

Jambeck, J.R., 2004. The Disposal of CCA-Treated Wood in Simulated Landfills: Potential Impacts. PhD Dissertation, University of Florida, Gainesville, FL.

Jang, Y., Townsend, T., 2003. Effect of waste depth on leachate quality from laboratory construction and demolition debris landfills. Environmental Engineering Science 20 (3), 183-196.

Khan, B.I., Solo-Gabriele, H.M., Townsend, T., Cai, Y., 2006a. Release of arsenic to the environment from CCA-treated wood: Part I leaching and speciation during service. Environmental Science and Technology 40 (3), 988-993.

Khan, B.I., Jambeck, J., Solo-Gabriele, H.M., Townsend, T., Cai, Y., 2006b. Release of arsenic to the environment from CCA-treated wood: Part II - leaching and speciation during disposal. Environmental Science and Technology 40 (3), 994-999.

McQueen, J., Stevens, J., 1998. Disposal of CCA-treated wood. Forest Products Journal 48 (11/12), 86-90.

Peek, R-D., 2004. EU directives and national regulations for the recycling and disposal of waste wood. Presented at the FICESS Conference, Orlando, FL, February 8-11, 2004.

Southern Forest Products Association. Forecasted Treated Southern Pine Markets for the US in the year 2000. SFPA, Kenner, Louisiana, 2001.

Solano, E., Ranjithan, S.R., Barlaz, M.A., Brill, E.D., 2002a. Life-cycle-based solid waste management. I: model development. Journal of Environmental Engineering 128 (10), 981992.

Solano, E., Dumas, R.D., Harrison, K.W., Ranjithan, S.R., Barlaz, M.A., Brill, E.D., 2002b. Life-cycle-based solid waste management. II: illustrative applications. Journal of Environmental Engineering 128 (10), 993-1005.

Solo-Gabriele, H., Townsend, T., 1999. Disposal practices and management alternatives for CCA-treated wood waste. Waste Management and Research 17, 378-389.

Solo-Gabriele, H., Townsend, T., Messick, B., Calitu, V., 2002. Characteristics of chromated copper arsenate-treated wood ash. Journal of Hazardous Materials 89, 213-232.

Solo-Gabriele, H., Townsend, T., Hahn, D., Moskal, T., Hosein, N., Jambeck, J., Jacobi, G., 2004. Evaluation of XRF and LIBS technologies for on-line sorting of CCA-treated wood waste. Waste Management 24 (4), 413-424.

Song, J., Dubey, B., Jang, Y., Townsend, T., Solo-Gabriele, H., 2006. Implication of chromium speciation on disposal of discarded CCA-treated wood. Journal of Hazardous Materials 128 (2-3), 280-288.

Thorneloe, S.A., Weitz, K.A., 2004. Sustainability and waste management. Presented at the Sustainable Waste Management Conference, November 17-19, New South Wales, Australia.

Townsend, T., Solo-Gabriele, H., Tolaymat, T., Stook, K., 2003. Impact of chromated copper arsenate (CCA) in wood mulch. Science of the Total Environment 309, 173-185. 
Townsend, T., Tolaymat, T., Solo-Gabriele, H., Dubey, B., Stook, K., Wadanambi, L., 2004. Leaching of CCA treated wood: implications for waste disposal. Journal of Hazardous Materials 114, 75-91.

United States Environmental Protection Agency (US EPA) 2002. Notice of receipt of requests to cancel certain chromated copper arsenate (CCA) wood preservative products and amend to terminate certain uses of CCA products. Federal Register, 67(36), 8244-8246. US EPA, Washington, DC.

United States Environmental Protection Agency (US EPA) 2003. A probabilistic risk assessment for children who contact CCA- treated playsets and decks. Draft Preliminary Report, Office of Pesticide Programs, Antimicrobials Division, November 10, 2003

Weitz, K., Barlaz, M., Ranjithan, R., Brill, D., Thorneloe, S.A., Ham, R., 1999. Life cycle management of municipal solid waste. International Journal of Life cycle Assessment 4 (4), 195-201.

Waste and Resources Action Program (WRAP), 2005. Options and Risk Assessment for Treated Wood Waste: Summary Report, ISBN 1900510-46-4. <http://www.wrap.org.uk/applications/publications/publication_details.rm?id=698\&publication $=2236>$. 